\title{
Por uma outra mise-en-scène: polifonia e afetividade no filme Welcome
}

\author{
Autor: Eliane de Oliveira \\ Orientador: Silvio Ricardo Demétrio
}

Resumo: Tradicionalmente conhecido como país de respeito aos direitos humanos e de asilo político, nos últimos anos a França recebeu notoriedade pela intolerância e expulsão de imigrantes. Muitas destas situações estão presentes em Welcome (Philippe Lioret, 2009) e provocaram um intenso debate social e político em torno da imigração. A visibilidade midiática de diferentes questões relacionadas ao tema possibilitada pelo filme culminou com o fim do delito de solidariedade - lei que punia cidadãos franceses que auxiliassem imigrantes em situação irregular no país. Para compreender as situações apresentadas na película utilizamos os estudos de Zygmunt Bauman (1999, 2005, 2007 e 2009), contextualizando o filme e sua produção. Em seguida, discutimos o processo de construção imagética com base nos conceitos de orientalismo de Edward Said (2007), e eurocentrismo de Ella Shohat e Robert Stam (2006), e as especifidades da França no tocante ao racismo, por meio das obras de Albert Memmi (1993) e Michel Wieviorka (1998). A presença do imigrante em Welcome foi identificada como tendo características polifônicas, de acordo com a perspectiva de polifonia de Mikhail Bakhtin. A partir do estudo de algumas características cinematográficas, fundamentado em Luís Nogueira (2010) e dos conceitos de imagem - afecção e rostidade de Gilles Deleuze $(1985,1995)$ entendemos que o uso de enquadramentos em primeiro plano teve como objetivo produzir uma individualização do imigrante e uma afetividade em relação a ele. Desta forma, acreditamos que Welcome contribui no sentido de ensejar novas possibilidades de ficcionalização do imigrante, bem como de outras minorias.

Palavras-chave: Crítica cinematográfica. Cinema. Estética. Semiologia (Cinema). 


\title{
For another mise-en-scène: polyphony and affectivity in the movie Welcome
}

\begin{abstract}
Traditionally known as a country of respect for human rights and political asylum in recent years France received notoriety by intolerance and expulsion of immigrants. Many of these situations are present in Welcome (Philippe Lioret, 2009) and provoked an intense social and political debate over immigration. The media visibility of different issues about the subjectwhich was possible because of the movie - ended with the expiration of the crime of solidarity, a law which punished french citizens who helped undocumented immigrants. To understand the presented situations by the movie, we use the studies of Zygmunt Bauman (1999, 2005, 2007 and 2009), contextualizing the movie and its production. Then, we discuss the imagetical construction process based on the concepts of Orientalism by Edward Said (2007), and Eurocentrism by Ella Shohat and Robert Stam (2006), and France's specificities about racism, using the work of Albert Memmi (1993) and Michel Wieviorka (1998). The presence of the immigrant in Welcome was identified with polyphonic qualities, according to Mikhail Bakhtin's perspective of polyphony. From the study of Luís Nogueira's cinematographic specificities and the concepts of image, affection and visage by Gilles Deleuze (1985, 1995) we understand that the use of close ups aimed to produce an individualization of the immigrant and an affection for him. This way, we believe that Welcome cooperates in the sense of rising new possibilities of the immigrant's fiction image, as well as about other minorities.
\end{abstract}

Keywords: Moving-picture criticism. Moving-picture. Aesthetics.

Dissertação completa disponível em: http://www.bibliotecadigital.uel.br/ document/?view $=$ vtls000192659 